\title{
Stygofauna of the Canary Islands, 23. A freshwater amphipod from La Gomera, Melita dulcicola n.sp.
}

\author{
J.H. Stock 1 \\ R. Vonk 1
}

Keywords : Taxonomy, Crustacea, Amphipoda, Melita, Canary Islands.

Description of a new species of Melita, $M$, dulcicola n.sp. (Amphipoda), discovered in a well fed by fresh ground water on the island of La Gomera in the Canary archipelago. This is the third limnic, oculate malacostracan crustacean becoming known from the Canary Islands, and it is the third species of Melita (with world-wide over 65 marine or brackishwater species) recorded from fresh waters.

Stygofaune des Iles Canaries, 23. Melita dulcicola n. sp. nouvel Amphipode d'eau douce de La Gomera

Mots clés : Taxonomie, Crustacea, Amphipoda, Melita, Iles Canaries.

Une nouvelle espèce de Melita, $M$. dulcicola n.sp. (Amphipoda) découverte dans une eau souterraine de l'île de La Gomera (Archipel des Canaries) est décrite.

C'est le troisième Crustacé Malacostracé oculé signalé des Canaries et la troisième espèce de Melita vivant en eau douce sur lęs quẹlquẹs 65 espèces marines ou saumâtres connues dans le monde.

\section{Introduction}

The only oculate freshwater malacostracans known from the Canary Islands are the two recently described species of the amphipod genus Rhipidogammarus, from streams and ground waters in Tenerife (see Stock 1988 and Stock \& Sánchez, in press). To our surprise, recent fieldwork on the Island of La Gomera yielded another oculate amphipod, this time found in a well fed by fresh ground water. It belongs to the predominantly marine/brackish genus Melita, a large and uneasy genus which comprises (if one includes the satellite genus $A b l u$ domelita) more than 65 species, of which only two are limnic : $M$. nitidula Ruffo, 1958, from torrents in Madagascar, and M. plumulosa Zeidler, 1989 , from a lake in New Zealand.

Since the Melita from La Gomera is (like almost all other species of the genus) perfectly oculate, and since the frehwater well in which it was found is not

1. Institute of Taxonomic Zoology, University of Amsterdam, P.O. Box 4766, 1009 AT Amsterdam. The Netherlands. far from the coast and at sea-level, we presume that the amphipod is a "recent " immigrant into the groundwater habitat, evolving from a marine ancestor. This idea agrees well with the notion of the relatively young geological age of the part of La Gomera where the amphipod was discovered. Since many close relatives of the genus Melita have penetrated into anchihaline, brackish of fresh waters in different parts of the world (e.g., Rotomelita, Nainaloa, Tegano, Allomelita, and others), the invasion of a Melita s.str. into the fresh ground water, is in interesting ecological conformity with the trend exhibited by several melitids.

Genus Melita Leach, 1814

Melita dulcicola n.sp.

Material examined. - Holotype (probably $\sigma^{\circ}$, body lenght $2.1 \mathrm{~mm})$, I paratype $(1,9 \mathrm{~mm})$. Canary Islands, La Gomera, sample 90-42 : well in banana plantation, village Playa de Santiago, Paseo La Laguna, less than $100 \mathrm{~m}$ from the coast, UTM coordinates BS $310215 \times 028420: 14.03 .1990$. Open well, diameter 4-5 m, with motorpump; duckweed and 
filamentous algae ; water level at $-5.40 \mathrm{~m}$, water depth $0.40 \mathrm{~m}$, water temperature $18^{\circ} \mathrm{C}$, conductivity $541{ }_{\mu} \mathrm{S} / \mathrm{cm}$ (corresponding with a salinity of $<0.3$ p.p.t.). Accompanying fauna : Cladocera, Cyclopidae, Planaria, Oligochaeta, Physa (Gastropoda), larvae of Odonata. Sample collected by J.H. Stock, E. Sánchez Rodriguez, and R. Vonk. Types in Zoölogisch Museum, Amsterdam, ZMA Amph. 108.770a-b (hologype dissected and mounted on slides in Faure's medium; paratype in alcohol).

\section{DESCRIPTION OF HOLOTYPE}

Body white ; eye round, small, black. Head with small cleft under the antennal lobe (fig. 1). Pleonites with some minute dorsal and dorsolateral setules. Urosomite 1 whit 1 dorsal tooth and pair of dorsolateral setules. Urosomite 2 with pair of lateral spines. Dorsum of other body somites naked.

Antenna 1 (fig. 19) : Peduncle segment 1 longest, segment 3 shortest. Accessory flagellum short, 2 -segmented; distal segment minute. Flagellum 9-segmented; segments 4, 5, 7, and 8 with slender aesthetasc (shorter than corresponding flagellum segment).

Antenna 2 (fig. 20) shorter than antenna 1 ; gland cone acuminate (fig. 21). Flagellum 6-segmented.

Upper lip (fig. 7) roughly pentagonal.

Mandible (fig. 9) with small, 3-segmented palp ; palp segment I unarmed; segment 2 with 2 ventral setae; segment 3 with 3 ventral setae and very long distal seta. Incisor of left mandible 5-dentate, right 4-dentate. Left lacinia mobilis 4-dentate, right lacinia indistinctly bifid (fig. 10). Both left and right molar with seta. Between lacinia and molar with 3 flattened spines +3 setae, of which 1 long (left), or with 2 flattened spines +1 long seta (right).

Lower lip (fig. 8) with distinct inner lobes.

Maxilla 1 (fig. 11) with narrow, slender, 2 -segmented palp. Distal end of palp with 2 setae +3 spines +2 setules ; spines of right palp slightly more slender than those of left palp. Outer lobe with 7 distal spines ; ornamentation of these spines (from lateral to medial) with $2: 2: 2: 2: 2: 1: 3$ denticles. Inner lobe narrow, rectangular, distally with 4 crooked setae.

Maxilla 2 (fig. 12) : Inner lobe without oblique row of setae.
Maxilliped (fig. 13-15) : Outer plate reaching distal end of palp segment 2 ; mediodistal margin with 9 spines. Inner plate reaching to middle of outer plate, armed with distomedial and distal setae only. Palp segment 3 swollen. Dactylus and unguis strong.

Gnathopod 1 (fig. 22) : Coxal plate 1.5 times as long as wide. Basis with 1 long seta on anterior margin. Merus with setulose patch. Carpus trapezoidal, subequal in length to propodus. Propodus with 1 group of setae on free posterior margin ; palmar angle poorly indicated ; palmar margin with some long setae and row of minute spinules. Claw with 2 and 2 distal setae.

Gnathopod 2 (fig. 23) with long coxal plate and large, globous, practically unstalked coxal gill. Basis without long setae. Merus without setulose patch but with pointed tooth on posterodistal corner. Carpu roundes-triangular, with short setation. Propodu trapezoidal; free posterior margin with 3 groups of short setae ; palmar angle marked by 1 spine and 3 or 4 long setae ; palmar margin with 2 swellings, sinuous, armed with 5 to 6 short setae only. Claw slender, dactylus with 2 endal and 1 distal setae and 1 spiniform process; unguis well demarcated, unarmed.

Pereiopod 3 (fig. 5) : Coxal plate wider than that of gnathopod 2 and coxal gill smaller, globular, almost unstalked. All segments very poorly armed. with sparse and short setae only.

Pereiopod 4 (fig. 6) somewhat shorter than P3 (merus and carpus markedly shorter). Coxal plate with high but shallow posterior emargination. Coxal gill ovate, stalk more distinct than in P3.

Pereiopod 5 (fig. 16) shorter than P6. Coxal plate anterolobate. Coxal gill smaller than that of $\mathrm{P} 4$, irregularly ovate. Basis more or less rectangular, posterior margin almost straight, with some 6 minute setules. Merus rather wide, carpus short. Claw long (c. $40 \%$ of length of propodus).

Pereiopod 6 (fig. 17) longer than P7. Coxal plats anterolobate, without ornamentation on anterior lobe. Coxal gill small, elongate ovate. Basis slightly tapering; posterior margin straight, with 5 minute setules. Claw almost $1 / 3$ of propodus.

Pereiopod 7 (fig. 18) : Coxal plate non-lobate. Basis with convex posterior margin. Claw slightly less than $1 / 3$ of propodus. 

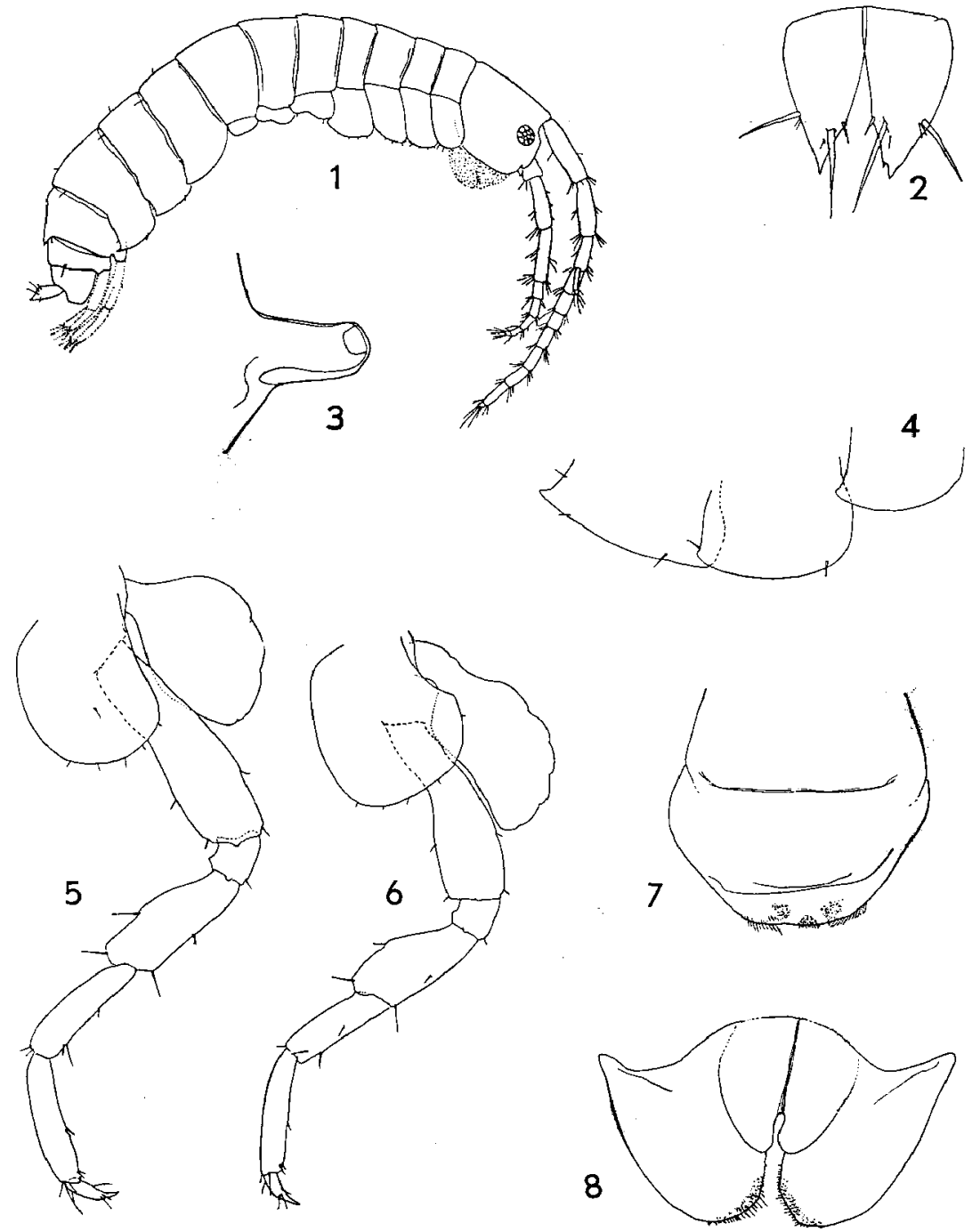

Fig. 1-8: Melita dulcicola n.sp. (fig. 1 drawn from paratype, remaining figures from holotype). 1, body from the right (legs and pleopods omitted) $; 2$, telson ; 3 , papilla on ventral surface of pereionite 7 , supposed to be one of the male genital papitlae ; 4 , epimeral plates 1 to 3 , from the right ; 5 , pereiopod $3 ; 6$, pereiopod 4 (to same scale as fig. 5 ) ; 7, upper lip ; lower lip. 
Epimeral plates (fig. 4) with small posteroventral point. Ventral margin of plates 2 and 3 with 1 spine.

Uropod 1 (fig. 24) : Peduncle with 1 ventral spine, placed far distal ; 1 long laterodistal spine, and 4 mediodorsal spines. Rami subequal ; exopodite with distal spines only ; endopodite with 2 dorsal and 4 (sub)distal spines.

Uropod 2 (fig. 25) without ventral peduncular spine ; dorsolateral margin of peduncle with 2 spines, and dorsomedial margin with 1. Endopodite with long dorsal spine.

Uropod 3 lacking in both specimens available.

Telson (fig. 2) deeply cleft, lobes tapering, acuminate. Armature : 1 lateral, 1 long dorsal, and 1 small medial spine; no distal spines [the telson resembles that of $M$. hergensis Reid, 1939 and $\boldsymbol{M}$. obtusata (Montagu, 1813)].

The holotype is presumably a male, since it lacks oostegites, and possesses a sclerotized, truncate tubercle on the ventral surface of pereionite 7 (fig. 3 ), supposed to represent one of the male genital papillae.

Etymology : the proposed specific name, dulcicola, is based on the Latin words dulcus (= sweet) and incola (= inhabitant), alluding to the freshwater habitat in which the species was found.

\section{REMARKS}

The description of this new species is a somewhat tricky business. First of all the material consists of only two specimens, both lacking their third uropods. Then, it is not quite certain whether the hototype is a male, female or subadult, because in many species of the genus (though not in all), the terminal male has a modified propodus in gnathopod 2, and the present material has not. By the absence of oostegites and the presence of a papilla on the ventral surface of pereionite 7 , the holotype is supposed to be a male ; whether it is a terminal adult or pre-adult cannot be made out (the low number of flagellum segments in antennae 1 and 2 seems to point to a pre-adult stage, however at least one interstitial species, Melita valesi S. Karaman, 1955, has a comparable, low number of segments in adults).

Whatever the age stage or sex of the specimens, we have decided to describe it in full detail, since the presence of ocellate freshwater Malacostraca in the Canary Islands is most exceptional, and since hitherto only 2 out of $>65$ species of Melita (s.1.) were known from fresh waters.

Our two specimens from La Gomera were alive when captured. A later, very intensive, sampling of the same well and the same area did not yield any further specimens. Notwithstanding all the drawbacks mentioned above, the Canarian material is attributed to a new species, because the combination of its non-age-dependent characters (such as the lateral head notch, the structure of maxillae 1 and 2) is incompatible with any of the known species. Less value is attached at this moment to the agedependent characters, such as the number of segments in the flagella of antennae 1 and 2, the setation of the legs, and the shape of the propodus of gnathopod 2.

Almost all species of Melita from the North Atlantic, have a triangular inner lobe of maxilla 1. armed in all species (except for $M$. reidi Hamond, 1965) with many setae. A few species, however, have a more or less rectangular inner lobe, armed with 4 to 6 setae only. When the setal number is low, the setea are concentrated usually at the distal end of the inner lobe ; when it is high, they occur all over the oblique medial margin of the lobe. The new Melita described in this note belongs to the group with a rectangular lobe, carrying few (4) setae. In the area under consideration, this group comprises $M$. bulla G.S. Karaman, 1978, $M$. valesi S. Karaman, 1955, M. leiotelson Vonk 1989 (all interstitial), and the epibenthic $M$. hergensis Reid, 1939. Several Pacific species have a similar first maxilla.

M. bulla, valesi, and leiotelson agree in several other characters with the Canarian taxon ; small, unpigmented body, poorly setose basis of gnathopods 1 and 2, absence of a greatly enlarged propodus in gnathopod $2 \mathrm{O}^{\circ}$, scarce armature of pereiopods 3 to 7 , a 2-segmented accessory flagellum in antenna 1 , a poorly setose mandible palp, etc. $M$. dutcicola appears to belong morphologically as well ecologically to this group of interstitial species.

Melita celericula Croker, 1971, " although not strictly infaunal » was " collected from coarse intertidal sands and gravels » in the Marshall Islands (Micronesia). It agrees with the other interstitial species in body size, mandible palp, maxilla 1 , and accessory flagellum, but it disagrees in gnathopod 


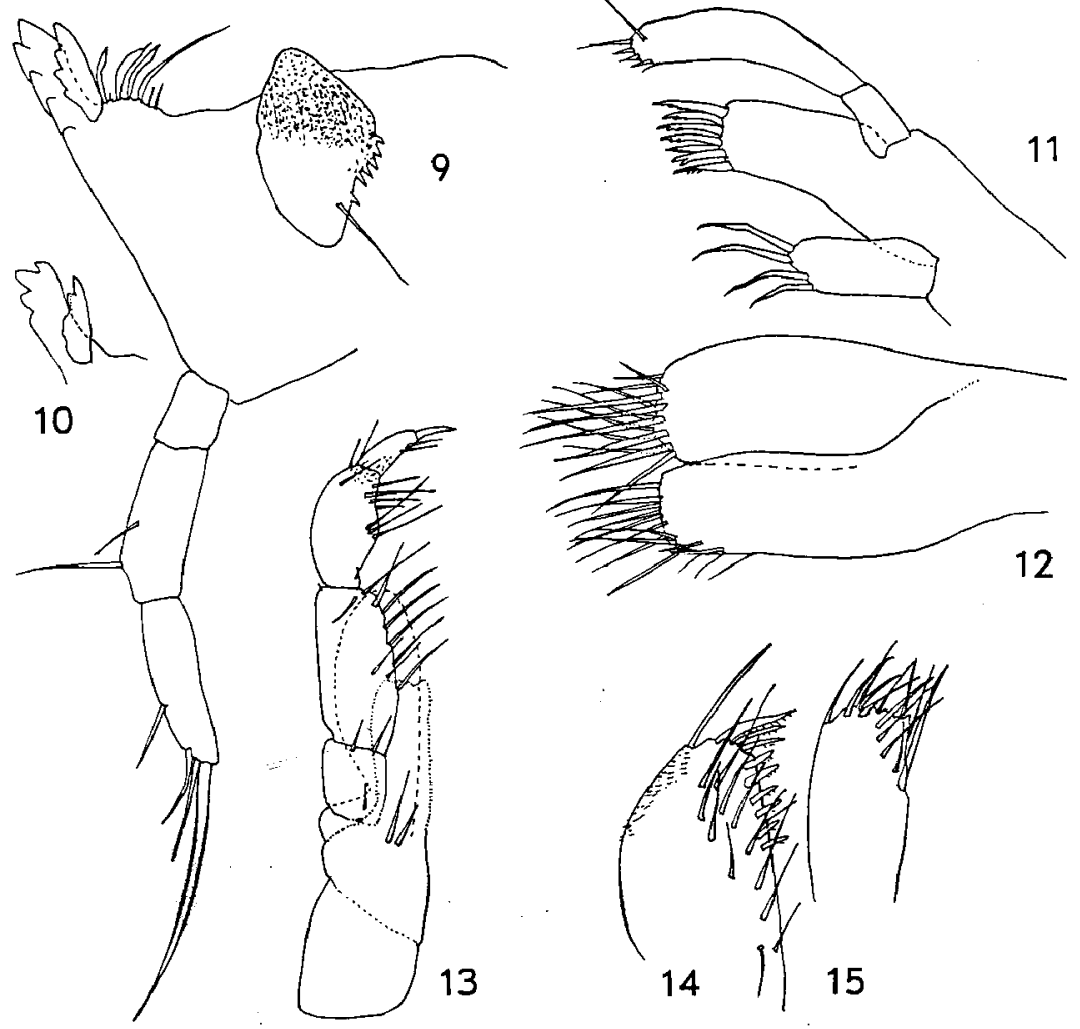

Fig. 9-15: Melita dulcicola n.sp. (holotype). 9, left mandible ; 10, pars inciviva of right mandible ; 11 , left maxilla 1 ; 12 , maxilla $2 ; 13$, maxilliped ; 14, outer plate of same; 15 , inner plate of same (figs 14 and 15 more strongly magnified than fig. 13). 


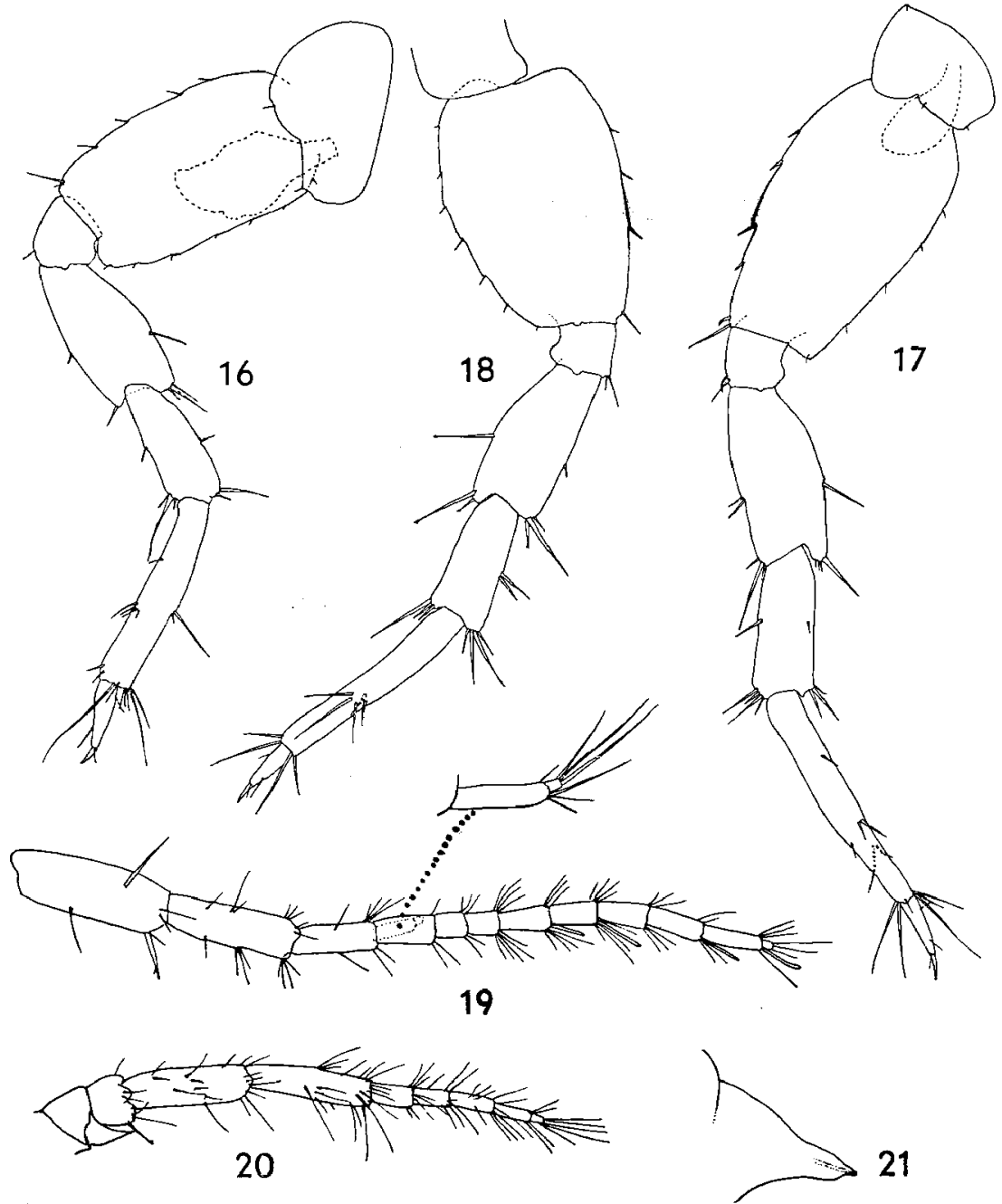

Fig. 16-21. Melita du/cicola n.sp. (hol -4ype). 16, pereiopod $5 ; 17$ pereiopod 6;18, pereiopod 7 (figs 16-18 to same scale); 19 , antenna 1 (accessory flagellum more strongly magnified) ; 20, antenna 2 (to same scale as fig. 19); 21 , gland cone of antenna 2 . 


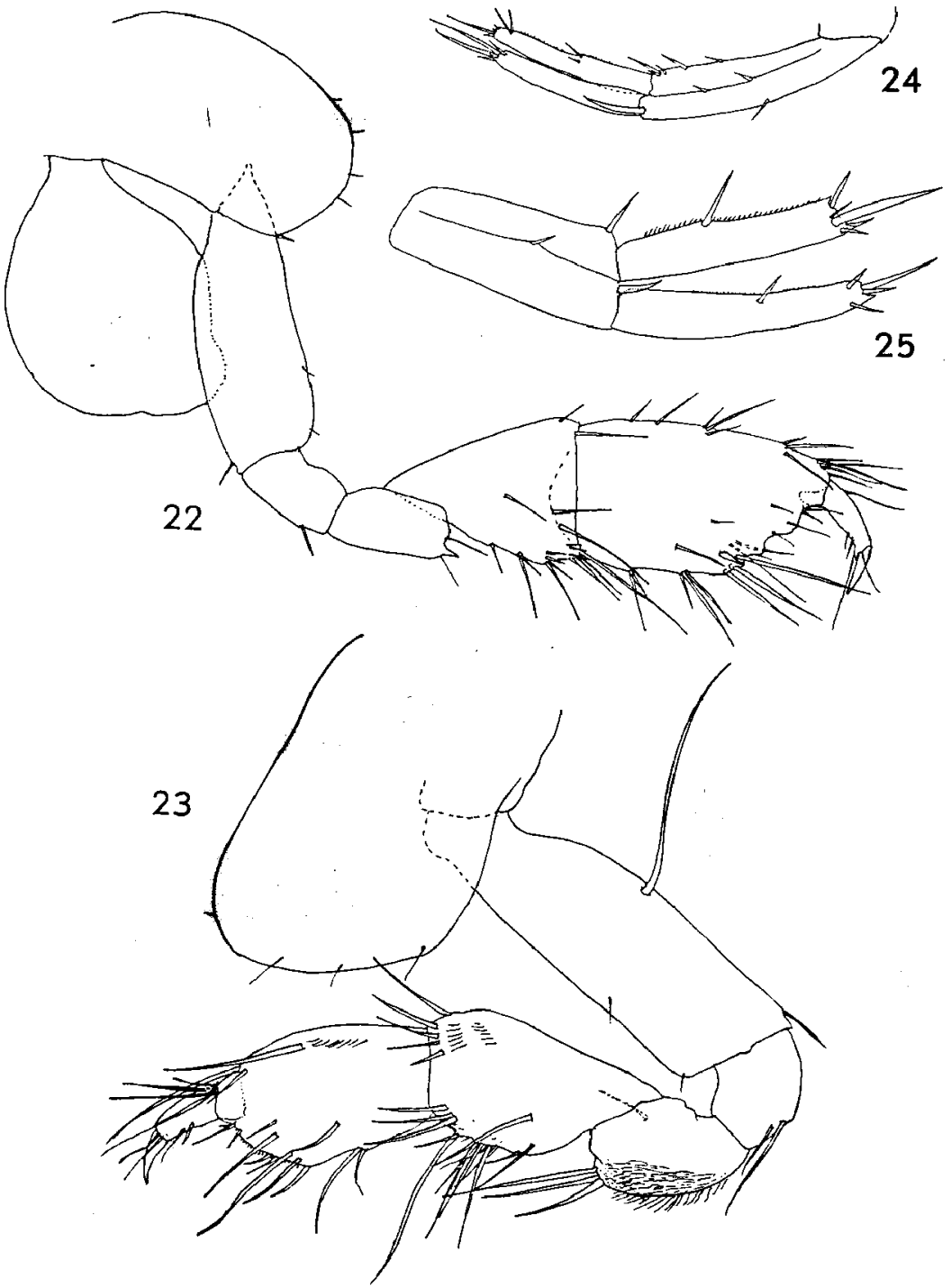

Fig. 22-25: Melita dulcicola n.sp. (fig. 24 drawn from paratype, remaining figures from holotype). 22, gnathopod $1 ; 23$, gnathopod $2 ; 24$, uropod $1 ; 25$, uropod 2 (not drawn to same scale as fig. 24) 


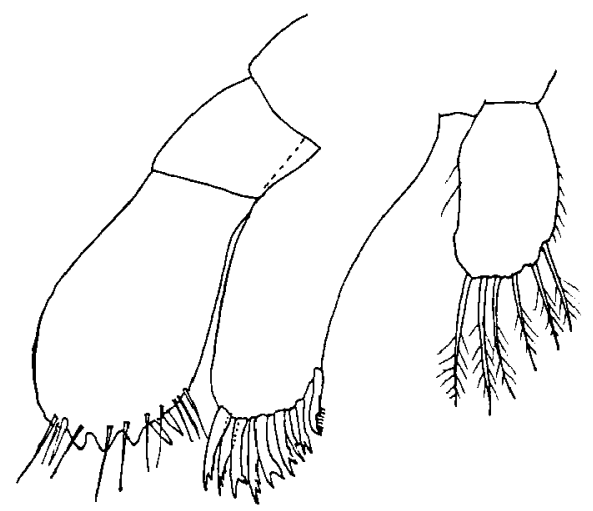

Fig. 26. Melita hergensis Reid, 1939, \& : maxilla 1.

morphology and setosity. $M$. celericula differs moreover from $M$. dulcicola in the shorter claws of pereiopods 5 to 7 .

Melita hergensis somewhat intermediate between the interstitial species and the epibenthic majority of the genus, with the latter group it shares its pigmented body, the heavily setose appendages, and the 2- to 4-segmented accessory flagellum.

All these species clearly belong to Melita s. str. and not to Abludomelita G.S. Karaman, 1981 (if this genus is distinct at all, see Zeidler 1989). They all differ from $M$. dulcicola in having a much shorter and wider (more or less clavate) distal palp segment in maxilla 1 (see fig. 26 for the first maxilla of $M$. hergensis, never illustrated before according to our knowledge). $M$. bulla, valesi, celericula, and hergensis differ moreover from $M$. dulcicola in harving an unnotched head; $M$. leiotelson differs in lacking telson armature. Urosomal armature is absent in $M$. bulla, valesi, and leiotelson, but present in hergensis, and celericula.

Special mention should be made of $M$. reidi Hamond, 1965, a presumably interstitial form from the North Sea coast of Norfolk. The inner lobe of its maxilla 1 is triangular, thus differing from that of $M$. dulcicola, but it bears only 4 (sub)distal setae. Lincoln (1979:294) considers $M$. reidi synonymous with $M$. obtusata, but Barnard \& Barnard (1983) list it as a separate species. For the moment, pending the discovery of the male, we will treat $M$. reidi as a separate species. The most striking differences between $M$. reidi and $M$. dulcicola reside in the unnotched head and the wide, clavate palp of maxilla 1 in reidi.

As to the two freshwater species of $\boldsymbol{M}$. nitidula Ruffo, 1958 and $M$. plumulosa Zeidler, 1939, the following can be said : although the mouthparts of M. nitidula (torrents in Madagascar) remained undescribed, it resembles the new species in the poorly setose gnathopods and pereiopods, and scarcely enlarged propodus of gnathopod $2 \sigma$, but its accessory flagellum is 3 -segmented, the claws of the pereiopods are much shorter, the urosome is untoothed, the telson spines are shorter, etc... M. plumulosa Zeidler, 1989 (freshwater pool in a quarry in New South Wales) shares the shape and armature of the inner lobe of maxilla 1 with the new species, but differs markedly in the strongly setose antennae and legs, the enlarged 2 nd gnathopod $\sigma^{*}$, the 3-segmented accessory flagellum, the short claws on the pereiopods, and the clavate palp of maxilla 1 . 


\section{Acknowledgements}

The fieldwork of the senior author and his co-worker, lic. Elias Sánchez Rodriguez of the University of La Laguna, has benefitted from the NATO Collaborative Grants Programme (Brussels), contrat SA. 5-2-05 (RG $001 / 88$ ). The junior author worked under a grant of the ERASMUS Student Mobility Action (Brussels), contract ICP-89-NL-0153/13.

\section{References}

Barnard (J.L.). 1972. - The marine fauna of new Zealand : algae-living littoral Gammaridea (Crustacea Amphipoda). Bull. N.Z. Dept. sci. ind. Research, $210: 1-216$.

Barnard (J.L.) \& Barnard (C.M.). 1983. - Freshwater Amphipoda of the world, Hayfield Associates, Mt. Vernon, Virginia, 830 p. in 2 vols.

Croker (R.A.). 1971. - A new species of Melita (AmphipodaGammaridae) from the Marshall Islands, Micronesia. Pac. Sci., $25:$ 100-108.

Hamond (R.). 1965. - On some Amphipoda from the coast of Norfolk, J. mar, biol. Ass. U.K., $45: 153-160$.

Karaman (G.S.). 1978. - On two Melita species (fam. Gammaridae) from the Mediterranean Sea, $M$. bulla n.sp. and $M$. valesi S. Kar., 1955, Boll. Mus. civ. St. nat. Verona, 5 : $221-237$.
Karaman (G.S.). 1981, - Redescription of M. planaterga Kunkel 1910 from Bermuda islands with revision of genera Metita Leach and Abludomelito n. gen. Poljoprivreda i Sumarstvo, $27: 29-50$.

Lincoln (R.J.). 1979. - British marine Amphipada : Gammaridea, British Museum nat. Hist. London : 1-658.

Reid (D.M.). 1939. - Melita hergensis sp. nov. (Crustacea, Amphipoda). Ann. Mag. nar. Hist., (11) $4: 278-281$.

Ruffo (S.). 1958. - Amphipodes terrestres et des eaux continentales de Magadascar, des Comores et de la Réunion. Mém. Insi. sci. Madagascar, (A) $12: 35-66$.

Stock (J.H.). 1958. - A new Rhipidogammaris (Crustacea, Amphipoda) from Tenerife : first record outside the Mediterranean and its biogeographic implications. Hydrobiologia, $169: 279-292$.

Stock (J.H.) \& Sánchez (E.). In press. - First record of Crustacea Malacostraca from freshwaters in the Canary Islands. Hydrobiologia.

Vonk (R.). 1989. - Nuuamu curvata n.sp. and Melita leiotelson n. sp. (Crustacea, Amphipoda) from beach interstitia on Curaçao. Studies in honour of Dr. Pieter Wagenaar Hummelinck Found. sci. Res. Surinam Neth. Antilles, 123 : 185-198.

Zeidler (W.). 1989. - A new species of Melita (Crustacea : Amphipoda : Melitidae) from northern New South Wales with a note on the genus Abludomelita Karaman, 1981. Proc. Linn. Soc. N.S.W., $110(4): 327-358$. 